\title{
MULTICULTURAL EDUCATION PRACTICES AND SOCIO-RELIGIOUS VALUES: The Study of Trans-Dalam Community in Central Kalimantan of Indonesia
}

\author{
Abdul Qodir \\ Institut Agama Islam Negeri (IAIN) Palangka Raya \\ Email:abdul.qodir@iain-palangkaraya.ac.id
}

\begin{abstract}
This article describes the practice of multiculturalism education among local migrant communities with Trans-Dalam community in Pulang Pisau regency, Kalimantan Tengah province, Indonesia, as its focus of analysis. It asks the question about how Trans-Dalam community members with diverse social and religious backgrounds develop multicultural practices in their daily lives. The required data were collected through in-depth interviews and observation. This article argues that Trans-Dalam villagers preserve and conduct multicultural ideas and practices as seen in their day-to-day harmonious communal life due to their shared local values and wisdom. Inspired by their own expressions of shared social-religious values, each community of different ethnic background develops these multicultural practices, which are closely connected to their need for security as settlers with diverse social-cultural backgrounds that make them aware of the importance of living in harmony, mutual respect, and solidarity regardless of their differences in ethnicity, place of origin or religion.
\end{abstract}

Key words: multiculturalism, education, practice, local, migrant, Trans-Dalam

\section{INTRODUCTION}

The notion of multiculturalism has been discussed by scholars from different disciplines in various forms of academic works. These include, among others, the works by van Tonder and Snootiness (2014), Sanchez and Salaberri (2017), Logviona (2016), Boeva (2016), Kyun et.al (2015), Ova (2014), Edewor and Aluko (2007), Rex and Singh (2003), Radtke (2003), Lian (2016), Haryanto (2013), and Ernas and Qodir (2013), Aytuga (2018), Astyrid (2017), Vervaet (2018), Webster (2017), Marshall (2017), Yampolsky (2016), Chaoa (2015), and Girdauskienea (2015). Undoubtedly, these studies provide important insight into understanding multiculturalism. However, this literature lacks empirical support that is based on the experience of community in the field where multicultural ideas and practices are closely connected to particular 
local social values, which are shared and adopted by the community members. To fill this gap, this article deals with the practices of multiculturalism in communities by focusing its analysis on local migrant communities in the rural area known as Trans-Dalam, which is located in Pulang Pisau regency, Kalimantan Tengah province, Indonesia. This site was chosen because it has characteristics that reflect how multiculturalism is practiced and lived by community members. For this purpose, by employing Maslow's concept of human needs as a theoretical framework, this article questions the development of multicultural ideas and practices in the rural communities of Trans-Dalam in Kalimantan Tengah.

This study of multiculturalism is important because it contributes to the promotion and preservation of open-minded attitude in order to live a peaceful live in pluralistic societies of the Indonesian archipelago. The rich and uniqueness of culture within and among Indonesian communities necessitate understanding of multiculturalism, which should be maintained and promoted by individuals, groups and institutions. For the purpose of this study, this article employed Abraham Maslow's theory of individuals' motivation as a theoretical framework. He developed a hierarchy of human needs, with which people attempt to fulfil their needs, from the lowest need (number 5) to the highest one (number 1). According to him, people attempt every effort to meet the important needs in a hierarchical way including the need for self-realization, the need for self-esteem, the need for a sense of belonging and a sense of love, the need for sense of security and the physiological needs (Maslow, 1993:43-57; Jarvis, 2010: 94). In the context of this study, the need for security is particularly seen as a central motivation that has played a significant role in creating and maintaining a multicultural society. My observation revealed that Trans-Dalam local migrant communities live a multicultural life due to their need for security. The findings of my field work serve to confirm Maslow's theory of human needs.

In general, multiculturalism is a notion or attitude that considers "cultural diversity" as the core of humanity, an inseparable bond with which people are willing to accept each other regardless of their differences. There are some terms that are often used interchangeably to describe a society with diversity in terms of religion, race, language, and culture. These are "plurality", "diversity", and "multiculturalism". These three terms do not actually represent the same thing, although they all refer to the state of plurality within society. The term "plurality" presupposes the existence of more than one entity. Meanwhile, the term "diversity" shows that the entity is not altogether the same, but rather heterogeneous and even unequal (Mulkan, 2006:4). 
Compared to two other terms, multiculturalism is relatively new term (Zulkarnaen, 2013). Different from "plurality" and "diversity", multiculturalism is a willingness to accept different groups as a whole, regardless of their varied entities of culture, ethnicity, gender, language, and religion. While plurality represents a non-singularity, multiculturalism gives affirmation that despite their differences, either visible or invisible, each group is entitled to have space in the public sphere of society. Multiculturalism has become a new policy in response to the diversity of communities. These communities not only need to be recognized as being different in nature from each other, but also be treated equally by the state (Zulkarnaen, 2013).

Multiculturalism as a movement demands the politic of recognition regarding all differences in society. These differences must be accepted, respected, protected and guaranteed (Zulkarnaen, 2013:5). Social order and prosperity are possible to achieve when aspirations for togetherness, mutual respect, spirit of progress, and inspiring ethos of advancement become the soul of multicultural society. The implementation of multiculturalism functions as a prevention as well as a solution to conflict and disharmony in a pluralistic society. For example, the implementation of multiculturalism through education can be an important means to solve socio-cultural conflicts. Multicultural education plays important roles in two ways: preparing individuals to be able to cope with new cultural waves of globalization and unifying national interests with various local cultures (Zulkarnaen, 2013:29). Both are taking place in the form of individuals' ability to face the challenges of living in harmony with one another.

Educational institutions like school can actually develop multicultural education according to the principle of school autonomy. This can be implemented using interconnected approaches to religious education by promoting, for instance, Islamic values of living in harmony with one another in society. People tend to know the stereotypes of an ethnic group more than what it is in factual ways. In the context of multicultural education, it is important to understand realities behind the apparent culture of an ethnic group. The implementation of multicultural education can be regarded successful when students or citizens develop tolerance and prevent hostility or conflict regardless of cultural, ethnic, language, custom differences. In addition, multicultural education nurtures students not to be uprooted from their own local cultures in the face of globalization. This can be pursued through several ways such as educating students about morality, good manner and etiquette as early as possible (Mahfud, 2010). 


\section{MULTICULTURAL PRACTICES WITHIN TRANS-DALAM COMMUNITY}

Trans-Dalam community is diverse in that its members came from various regions in Indonesia. Some came from outer Kalimantan islands such as Java, Bali and Nusa Tenggara. Others came from inland Kalimantan regions like Kapuas and Banjarmasin. Through the transmigration program of the Ministry of Transmigration, those from Java came to Trans-Dalam by ship in 1982 and those from Bali and Nusa Tenggara got there in 1983. Meanwhile, most of community members with local Kalimantan background came to TransDalam voluntarily, not through the government program of transmigration.

Trans-Dalam community is also diverse in terms of religious background. The community members have various religious faiths; most of those with Javanese and Banjarese backgrounds are Muslims, those from Kapuas with Dayak background and from Nusa Tenggara are Christians, and those from Bali are Hindus. These migrants came to Trans-Dalam to find a better future. They were treated equally by local government regardless of their backgrounds. When they came, each family was given 2 acres of land, allowances which were worth two year living expenses and a modest house. Compared to other migrant communities in Pulang Pisau regency, Trans-Dalam is considered the most diverse migrant community. Led by a village chief (kepala desa), TransDalam consists of 20 groups of household called rukun tetangga, just like other communities in Indonesia.

\section{Socio-Religious Interaction}

Trans-Dalam villagers developed interaction that took place any time in their convenience. This interaction occurred between individuals within the same faith group and culture or among those with different faiths and cultures. The interaction, which occurred warmly or incidentally among community members with different faiths, united those engaged in the shared religious values of social interaction and hindered misunderstanding, especially in issued related to personal hygiene and food. The peaceful interaction within Trans-Dalam communities made the villagers possible to establish solidarity and unity among them. This in turn created awareness of the importance of living in harmony among the villagers so that their social and economic lives run smoothly without any friction. A Trans-Dalam community member gives an interesting statement below.

I think I have never seen any problems that disturb people here. I feel nothing disturbs me so that is why I feel at home here. Feeling happy, 
that's all. I see harmony in terms of religious or social relations. Even in Idul Fitri festival, we cannot differentiate between Muslims and Christians as they are busy helping each other. It is good here. In market, for example, we are all the same. We find no discrimination. I don't understand. Even the elders mingle with one another; either they are Javanese, Banjarese, or Dayaks. All attend every congregation which is regularly arranged. In this surrounding, in this market area of Block 16, whenever you meet a Banjarese, you will find him being together with a Javanese [community member].

This was supported by a Christian community member:

We help each other, trying to ease the burden of our neighbourhood. When Muslims are busy in welcoming Id festival, I as a Christian lightheartedly assist them to prepare meals. In the same way, later during Christmas, or other Christian festivals, Muslims help Christians. So it's been routine. I, together with my son and husband, and [my Muslim neighbours] visit each other in our surrounding. Women usually prepared sweets or food. There are no constraints to our relationship with our neighbours.

The community members loved to help each other due to mutual recognition, mutual trust, and then mutual respect among themselves. Visiting each other among Trans-Dalam community members at the commemoration of religious holidays was considered an important moment. However, this was restricted to social interactions, avoiding participation in shared rituals or worship. For Muslims villagers, this was in accordance with a Quranic verse that says "For you your religion and for me my religion" (Qur'an 109: 6).

The Trans-Dalam villagers were also keen to share with those in need. Those who were successful in their farming normally donate some of their crops to help neighbours or colleagues in need so that no one was reported to experience short of food. Crop production in rural areas increased significantly for community members worked in safe and secure conditions. No anxiety was felt by Muslims, Christians and local belief Dayak adherents. This condition had been realized in Trans-Dalam since the transmigration program was launched by government in the early 1980s, which brought local migrants from Java, South Kalimantan and other cities in Kalimantan. Therefore, Trans-Dalam community lived a harmonious life regardless of their social, cultural and religious differences. A community member reported the following notes.

There are three ethnic groups here: Banjarese, Javanese, and Dayak Kapuas. They never have a dispute resulting from differences in religion. Disputes may occur among teenagers because of their delinquency, 
not because of religious or ethnic differences. Once it was heard that [religious conflict] broke out in Pangkoh. But, it was fake news. I saw it myself [that it was fake]. Rumour [about conflict] sometimes scares us. In fact, no conflict happens here. It is peaceful here.

Trans-Dalam community members felt comfortable, secured and safe in their neighbourhood. The local migrants from Java, for example, were seen to be different in terms of background, ethnicity and belief. But, in everyday life, they were treated in a good and respectful way in spite of their origin of place. The Trans-Dalam communities developed and lived a harmonious life among themselves regardless of their various social-cultural backgrounds. A villager said:

[All community members] are united, supportive of each other and helpful of each other. It is how they live here. Look, for example, my neighbour $\mathrm{Bu}$ Intan. Her husband is a Banjarese. He is good to my family and me. No word of insult or offensive comment has ever been heard from him. There is indeed a mutual respect. Another example is a school teacher Bu Ainun who is from Banjar. She has been kind to us so far. For tens of years we know her. The school headmaster is from Java, Pak Tohari. Yes, he is like brother to us. We have been good colleagues since our school times. ${ }^{1}$

In Trans-Dalam community, native people of Kalimantan Tengah (Dayak Kapuas), local migrants from Kalimantan Selatan and Java developed a meaningful interaction. This interaction appeared to have something to do with their shared psychological experiences. The three ethnic groups tended to focus on their own family business, avoiding the intervention of their neighbours' affairs or colleagues' personal issues. In other words, these ethnic groups developed a self-control, which made them able to avoid interfering with one another. Trans-Dalam consisted of some communities with different ethnic groups. This meant there were a variety of customs, traditions, and ordinances and so on. However, those who came from outside Central Kalimantan seemed to be able or were smart enough to place themselves within new community in a peaceful way and make themselves useful to all people. For Muslim villagers, this attitude was inspired by an Islamic teaching that "The best person among you is he or she who makes himself or herself most useful to people around him or her".

${ }^{1}$ Interview with Sri Wahyuni (50 years old) and her husband, Wahyu (53 years old), 20 December, 2013. Their two children, now working in provincial ministry of general constructions, gained a degree from faculty of technology in a university in Palangka Raya.

${ }^{2}$ This refers to a saying by the Prophet Muhammad: Khayr al-nas anfa'uhum li al-nas 
Trans-Dalam was conducive to develop peaceful interaction among community members with different religious background. The fact that most community members live close to each other made them easy to communicate and interact. Most villagers knew each other and were acquainted to each other. This in turn created the sense of security and trust among people in Trans-Dalam. A community member said:

It is safe here. There has never been conflict between ethnic groups. All people get along well. Here everyone is happy. During religious festivals, everyone pays a visit to each other. My Muslim neighbours have no problem in visiting me to celebrate the holidays together, though I am a Christian. Although our Christian people are small in number, about four to six families in this area, and $98 \%$ of the community members are Muslims, [we live peacefully and respect each other]. ${ }^{3}$

The visit to enhance social-religious interaction was not only developed between community members with different social-religious backgrounds, but also within those with same faith. This was popularly known as silaturrahim. In Trans-Dalam, there were groups with the same ethnic groups, place of origin or religious organizations, which were known as paguyuban. These included Dulangmas and Pakuwojo paguyuban of Javanese background in Central Kalimantan, and Bakumpai community of Dayak origin. In particular, Banjarese people who lived near Pasar Rebo market also expressed their gratitude for living next to people from other regions and different ethnic backgrounds. A Banjarese described how they treated other people with different backgrounds.

We are from Banjar. There are just 17 families that live in Hulu Sungai Selatan Regency... In the area Pandih Batu, a subdistrict of Hulu Sungai Selatan, the percentage of Muslims and non-Muslim is equal, fifty-fifty. In this trans-settlement, 99\% of its people are Muslims. We are united here. There is no conflict. They respect each other. Banjarese and Javanese villagers have the same creed. Yes, we are in fact brothers. ${ }^{4}$

Banjarese villagers loved to live next to the market as they were quite talented in trading and business negotiation. They preferred staying at business centres to living at farmlands. They also loved to live near mosques or Islamic educational institutions such as madrasah or pesantren to gain Islamic knowledge. This attitude surely stemmed from their obedience to an Islamic doctrine that all

(the best people are those who are the most useful to others).

${ }^{3}$ Interview with Sri Wahyuni, 11 August 2013.

${ }^{4}$ Interview with Normansyah (53 years old), 11 August 2013. 
Muslims, male and female, must search for knowledge and achieve happiness here and hereafter. The Banjarese people's interests in commercial transactions combined with their stay in Pasar Rebo market in Trans-Dalam area, was not only motivated by economic progress, but also by religious. In their business, they were highly motivated to collect money in order to perform Hajj or Pilgrimage to Mecca on their own, not by government or institutional support.

Other community members of different ethnic groups also felt strongly connected with Trans-Dalam settlement. This was true for the case of Sri Wahyuni and her husband. They decided to live next to Banjarese people who had already lived in Trans-Dalam earlier. They felt comfortable for being close with the Banjarese, forming a strong bond between them in Pasar Rebo market. A community member said:

The number of Banjarese is quite a lot in this market, around Pasar Rebo, while in other place they are rare. These people like to work as traders. They had lands before, but did not want to build houses on the land so that they sold them. ${ }^{5}$

The places of origin were considered to have given influence to the way of life or work after marriage. When grown up, Banjarese villagers in Trans-Dalam normally did the work which was previously experienced since childhood. For instance, Normansyah from Anjir Pasar participated a local transmigration program with his friends who were working as traders. Norman and his friends sold their houses located near farms to build new houses next to Pasar Rebo market. They already had experience as traders of everyday needs in the market, so they pioneered the business though the market was opened one a week. Another kind of job in which the Banjarese local migrants in TransDalam were skilled at was fishing. The Dayak and Javanese people in the village highly admired their skills. They said: "Banjarese people, some of them love to trade, while others prefer catching iwak (fish). During drought season, they can make so much money from fishing." 6

\section{Marriage}

In addition, the multicultural practice among Trans-Dalam community was seen in inter-ethnic marriages, which were quite common among the community members. This was evident, for example, in the case of Wahyu, a Javanese, and Sri Wahyuni, a Dayak. Sri Wahyuni said:

${ }^{5}$ Interview with Norman (53 years old), 11 August 2013.

6 Interview with Tohari (53 years old), a Muslim Javanese leader, 25 December 2013. 
I am married to Pak Wahyu, a gentleman from local transmigration settlement, an employee of the ministry of transmigration. He is from Bojonegoro, Java. He was previously a temporary worker in Unit Pemukiman Transmigrasi (UPT; Transmigration Resettlement Unit). I got a diploma here, then participated in transmigration projects in 1982. We have been here (Trans-Dalam) since 1982. Previously we were in Kuala Kapuas... ${ }^{7}$

This kind of marriage was evidence that Trans-Dalam community was committed to a collective life, which was supported by their socio-religious values. Wahyu, Sri Wahyuni's husband, was a civil servant who didn't have a university degree. The couple was always gratitude for the harmonious marriage they had though they came from different cultural backgrounds in hand. Their family life was embellished with bright and diligent sons whose university studies were completed in less than 8 semesters. Their sons then got jobs easily. Sri believed that marriage of a man and a woman who have no family relationship or have different ethnic groups may result in children who are smart, persistent in pursuing their goals and devoted to their parents. She remarked:

Our first son graduated from the faculty of economics at University of Palangka Raya. He got a job at the office of public works in Palangka Raya. Then, he was married to a Banjarese Muslim who works at the same office.

The same case holds true for the case of Subandi, an East Javanese Muslim who was married to Kristy, a daughter of a Catholic leader from Kapuas. Subandi said:

My wife (Kristy) converted to Islam at the time of our marriage preparation. She had an approval from her parents to marry me. At that time, Kristy was an elementary school teacher. We have three children: the first and second children are boys and the third one is a girl. They went to study at a modern Islamic boarding school in East Java. The boys pursued their undergraduate studies at English department at a university in Malang, East Java. Then, they continued to do master program in English at Sarjana Wiyata University Yogyakarta. We have a good relationship and good communication with Kristy's parents and relatives though we have different faiths. ${ }^{8}$

7 Interview with Sri Wahyuni and her husband, Wahyu, 11 August 2013.

8 Interview with Subandi (53 old years) and Kristy (50 years old) in Trans-Dalam, 20 December 2013. 
Moreover, to some extent, multicultural practice changed the way TransDalam communities plan marriage. For example, community members with Javanese backgrounds no longer used a Javanese tradition of taking the birthday of potential bride and groom into consideration in deciding the time of marriage and choosing one as wife or husband. This was seen in the case of the marriage of Wahyu and Sri's son. Their son and his future wife were married on their own choice as they loved each other, disregarding their different ethnic groups. Their parents and extended families supported their marriage without any problems. Wahyu said:

My son was married to Mariah Qibtiah according to Islamic law of marriage. He took her as his wife by himself and we gave them our support to build a better future. We are Christians, but my parents in East Java are Muslims, and my daughter in law is a Muslim. This is not a source of conflict in our lives. ${ }^{9}$

The multicultural practice was also seen in the case of Petrus Sukarmin. Due to financial difficulties he experienced, he converted to Christianity. But, he then converted back to Islam when he was about to get married to a Muslim girl who graduated from an Islamic boarding school. He said:

I am a teacher at at a middle school. I was married to Siti Rahmini, an orphan with three brothers. Siti is a Javanese woman who graduated from Darul Hijrah Islamic boarding school. We live in harmony. My wife told me about Islamic teachings. Frankly, I tell you, I have a unique experience; I converted to Christianity when I studied at senior high school in Pandih Batu and was given a name Petrus Sukarmin. ${ }^{10}$

\section{Funeral}

Lastly, the practice of multicultural life among Trans-Dalam community was identified in the way they responded to the funeral procession of a dead community member. Regardless of their religious backgrounds, Banjarese, Javanese and Dayak people worked hand in hand in conducting the funeral of a dead fellow community member. During this funeral procession, Muslims visited and offered assistance to non-Muslim family of a dead person and vice versa. A community member reported:

I am from Kapuas and am a Dayak. I work at Community Health Centre and stay in a house which was provided by the centre. We are surely

9 Interview with Wahyu (53 years) in Trans-Dalam, 20 December 2013.

${ }^{10}$ Interview with Petrus Sukarmin, 23 December 2013. 
in grief when one fellow is dead. As Muslims, we arrange the funeral procession without taking into account his or her religious background. I don't think there is any dispute in this matter. We take the dead person to the cemetery and bury it there. [We do this] though the number of Christians in our neighbourhood is decreasing at the moment. ${ }^{11}$

The same is true when a Muslim dies. People from the neighbourhood were involved in preparing and conducting the funeral regardless of their religious background. A Muslim community member said:

In the funeral process of a dead Muslim, such as saying prayers for the dead person in the seventh, fortieth and hundredth day after their death, it is common that the dead person's neighbors come and lend their hands regardless of their faith or ethnic backgrounds. Some cook food, while others give donation. ${ }^{12}$

Moreover, this multicultural practice was seen in the way they manage the burial place for the dead person. The Muslim and Christian cemeteries were separated by a kind of border, but located in the same piece of land. A Muslim said:

Muslim and Christian cemeteries are located in a piece of land, but both are separated by a simple border as seen in Kantan Muara village; on one side is Muslim cemetery, and on another one is Christian cemetery. ${ }^{13}$

\section{MULTICULTURAL PRACTICES AND SOCIO-RELIGIOUS VALUES}

The multiculturalism practices as described above did not work alone, but rather were closely connected to socio-religious values adopted by the people of Trans-Dalam. Therefore, it is important to reveal what socio-religious values which contributed to the multiculturalism practiced by Trans-Dalam communities. As the communities consist of members with various ethnicity, social and cultural backgrounds and came from different regions of origin, these social-religious values should be found within each of these ethnic groups in Trans-Dalam. Accordingly, these values are reflected in proverbs, expressions or sayings which are shared and lived by each community. As Bonvillain (1997:48) emphasizes, lived expressions constitute a community's cultural modes of mentality, attitudes, perception, ethics, morality, and socialreligious values.

\footnotetext{
${ }^{11}$ Interview with Norman in TransDalam, 11 August 2013.

${ }^{12}$ Interview with Abdul Ghofur in Trans-Dalam, 1 Desember 2013.

${ }^{13}$ Interview with Abdul Ghofur in Trans-Dalam, 1 Desember 2013.
} 
My findings revealed that Trans-Dalam community members of Javanese origin developed certain values as its local wisdom to create and maintain a harmonious multicultural life. This is seen in the Javanese proverbs and expressions shared by the Javanese community members in Trans-Dalam in their daily lives. These include the expressions giri lusi janna kena ingina (one never insults another), aja adigung, adigung, adiguna (do not be an arrogant self); ngono ya ngono, ning aja ngono (you may make a mistake, but do not repeat it); tuna satak bati sanak (brotherhood); and aja kumingsun (one never shows of force and degrade another). They also lived social wisdom which guide community elders and leaders how to lead their people and get along with other people of different groups in proper ways, as expressed in the saying of ing ngarsa sung tulada, ing madya mangun karsa, tut wuri handayani (elders should be exemplary models, motivate and inspire their people). All these shared and lived expressions of local Javanese wisdom played an important in providing the Trans-Dalam community of Javanese background norms and values of how to live with other communities in a harmonious way.

The Trans-Dalam community of Balinese background also developed and maintained social-religious values in their attempt to live a multicultural life as expressed in the proverbs of local wisdom such as desa kala patra (place, time and situation). This teaches them that they should live in accordance with shared local customs of the place where they live and the situation they are engaged with as well as with their religious teachings of Hinduism. Among the community with Banjarese backgrounds, there were proverbs and expressions of social-religious values shared and lived by its members in their practice of multicultural life. These include berelaan (accepting each other and being thankful to God), bisa-bisa maandak awak (adapting oneself to a new environment), bubuhan (friendship), bedingsanakan (family bond), batutulungan (one helps another), bakalah bamanang (win-win solution), gawi manuntung (do your work well), and dalas balangsar dada (hard work). This wisdom provides the Banjarese community with values of deliberation, brotherhood, helping each other, adjusting to local culture and customs, and maintaining good relationship between people and God, and among people.

Moreover, there were various expressions of shared local wisdom that provided guidance to Trans-Dalam community of Dayak background in its interaction with other communities in peaceful ways. These include hapahari (togetherness), handep (helping each other), pandohop (providing aid), belom bahadat (living in accordance with shared ethics and customs), hapakat kula (deliberation), sama keme, sama mangat, sama susah (living together in good and bad), and hatamuei lingu nalata (one should know, share ideas 
and experiences with another). Undoubtedly, these expressions and sayings of social-religious values and wisdom shared and lived by Trans-Dalam communities with different social and cultural backgrounds reflected their views, perceptions of themselves and attitude towards each other. At the same time, these played an important role as guidance for the communities in living their lives and building connection with each other in multicultural ways.

\section{CONCLUSION}

This article has contributed to the studies of multiculturalism of education by empirically showing that as seen in the case of Trans-Dalam villagers migrant communities with various social, cultural and ethnic groups were able to maintain and implement multicultural practices in their day-to-day lives as they were motivated and inspired by social-religious values which were seen in the expressions and proverbs shared and lived by each community with different ethnic backgrounds. Trans-Dalam villagers preserved multicultural ideas and conducted multicultural practices. This was intrinsically derived from understanding and applying the shared social values and religious teachings that commanded everyone to cooperate with one another in every good matter. They interpreted and implemented these values in a broad sense, as seen in their willingness to work together and help each other in ways that benefit their common interests.

Understanding multiculturalism has not been well achieved unless one takes factors related social, cultural, and religious values shared and lived by a community into consideration. Inspired by their own expressions of shared social-religious values, each community of different ethnic background developed multicultural practices in its social and religious interaction including marriage, funeral and religious festivities. Confirming Maslow's theory of human needs, this finding was closely connected to the communities' need for security as settlers with diverse social-cultural backgrounds that made them aware of the importance of living in harmony, mutual respect, and solidarity regardless of their differences in ethnicity, place of origin or religion.

\section{BIBLIOGRAPHY}

Aytuga, G. Z., Ruab, T., Brazeala, D.V., Almaraza, J.A., Gonzáleza, C.B., (2018). A Socio-cultural approach to multicultural experience: Why interactions matter for creative thinking but exposures don't. International Journal of Intercultural Relations. Volume 5, No. pp. 29-42. https://doi. org/10.1016/j.ijintrel.2018.03.004. Accessed on 15 December 2018. 
Boeva, A. (2016). Discursive construction of refugees, migrant and asylum seekers in British and American news sources. Procedia-Social and Behavioral Sciences 236, pp. 53-58. https://www.sciencedirect.com/ science/article/pii/S1877042816316512.

Bonvillian, N. (1977). Language, Culture and Communication: The Meaning of Message. New Jersey, United States : Prentice-Hall.

Chaoa, M., Melody, Kungb, F.Y.H., Yaoa, D.J., (2015). Undersdtanding the divergent effects of multiculturalexposure. International Journal of Intercultural Relations, pp.78-88. http://dx.doi.org/10.1016/j.ijinterel.2015.03.032.

Edewor, P. A. and Aluko, Y.A. (2017). Diversity Management, Challenges and opportunity in Multicultural Organizations, International Journal of The Diversity Vol. 6. No. 6. http://eprints.covenantuniversity.edu. ng/589/1/Diversity_Management,Challenges_and_Opportunities_ in_Multicultural_Organisations.pdf.

Ernas, S and Qodir, Z. (2013). Tantangan Global dalam Perubahan Lokal, Vol. 2, No. 2, Jurnal UGM, pp. 43-58. https://jurnal.ugm.ac.id/jps/issue/ view/3108.

Girdauskienea, L. \& Eyvazzadeb, F. (2015). The profile of an effective female leadership in multicultural context. Procedia - Social and Behavioral Sciences, volume 210. pp.11 - 20. doi: 10.1016/j.sbspro.2015.11.323.

Gromova, C.R. \& Hayrutdinova, R.R. (2017). Multicultural training of the teacher for work with children of Muslim migrants. Procedia - Social and Behavioral Sciences 237, pp. 288 - 291, 7th International Conference on Intercultural Education Education, Health and ICT for a Transcultural World, EDUHEM 2016, 15-17 June 2016, Almeria, Spain. doi: 10.1016/j.sbspro.2017.02.078.

Gundemira, S., Homanb, A.C., Usovac, A., Galinskya, A.D., (2017). Multicultural meritocracy: The synergistic benefits of valuing diversity andMerit. Journal of Experimental Social Psychology. Volume 73 pp. 34-41. http://dx.doi.org/10.1016/j.jesp.2017.06.002.

Haryanto, J. T. (2013). Dinamika Kerukunan Intern Umat Islam dalam Relasi Etnisitas dan Agama di Kalteng, Analisa, Vol. 20, No. 01, pp. 13-24. https://blasemarang.kemenag.go.id/journal/repository/analisa-vol20-no-1-juni-2013.

Jarvis, M. (2010). Teori-teori Psikologi. (translated by SPA-Teamwork), Bandung: Nusa Media. 
Josefová, A. (2014). The Cultural Diversity as a Phenomenon of the Multicultural Society. Procedia-Social and Behavioral Sciences 152, pp. 1019 - 1021. https://www.sciencedirect.com/science/article/pii/ S1877042814053336.

Kyun, J., Chung, K., Ryu, S., and Han, A. (2015). Multicultural Education in a Korea Early Childhood Classroom: Based on the Educational Community Perspective. Procedia - Social and Behavioral Sciences 174, pp. 2036-2039. https://www.sciencedirect.com/science/article/pii/ S1877042815009258, accessed on 22 February 2018.

Lian, K.F. (2016). Multiculturalism in Singapore: Concept and Practice. In Lian K.F. (ed.) Multiculturalism, Migration, and the Politics of Identity in Singapore. Asia in Transition,. pp. 11-29. https://www.springer. com/gb/book/9789812876751.

Logvinova, O. K. (2016). Socio-pedagogical Approach to Multicultural Education at Preschool, Procedia Social and Behavioral Sciences, Volume 233, pp. 206-210. https://www.sciencedirect.com/science/article/ pii/S1877042816314367.

Mahfud, C. (2013). Pendidikan Multikultural. Yogyakarta, Indonesia: Pustaka Pelajar.

Marschall, S. (2017). Transnational migrant home visits as identity practice: The case of African migrants in South Africa. Annals of Tourism Research volume 63, pp. 140-150. http://dx.doi.org/10.1016/j.annals.2017.01.011. Accessed on 24 December 2018.

Maslow, A. (1993). Motivasi dan Kepribadian, translated by Nurul Imam, Bandung, Indonesia:Remaja Rosdakarya.

Mulkhan, A. M. (2004, September 28). Pendidikan Monokultural Vs Multikultural dalam Politik. Kompas, pp.A2.

Radtke, F.O. (2003). Multiculturalism in Germany: Local Management of Immigrants Social Inclusion, International Journal on Multicultural Societies, Volume 5, No. 1, pp. 55-76. http://www.unesco.org/new/en/ social-and-human-sciences/resources/periodicals/diversities/past-issues/vol-5-no-1-2003.

Rex, J. and Singh, G. (2003). Multiculturalism and Political Integration in Modern Nation-State. International Journal on Multicultural Societies (IJMS), Volume 5, No. 1, pp. 3-19. http://unesdoc.unesco.org/images/0013/001387/138796E.pdf. 
Sanchez, L. C. and Salaberri, S. (2016). Multiculturalism and Internationalization in Spanish Universities-North-South Socio-Cultural Differences. 7th International Conference on Intercultural Education, Health and ICT for a Transcultural World (EDUHEM), 15-17 June 2016, Almeria, Spain, Procedia-Social and Behavioral Sciences, Volume 237, pp. 1125-1130. https://www.sciencedirect.com/science/article/pii/ S1877042817301660.

Sunarto, K., Hiang-Khng Heng, R., Saifuddin, A.F. (eds.). (2004). Multicultural education in Indonesia and Southeast Asia: Stepping into the Unfamiliar. Jurnal Antropologi Indonesia.. Volume X,pp. 20-30.

Tonder, C. L. van and Soontiens, W. (2014). Migrant Acculturation and the Workplace. Procedia - Social and Behavioral Sciences, Volume 143, pp. 1041-1047. https://www.sciencedirect.com/science/article/pii/ S1877042814044784.

Vervaet, R., Houtte, M.V. \& Stevens, P.A.J. (2018). Multicultural school leadership, multicultural teacher culture and the ethnic prejudice of Flemish pupils. International Journal of Teaching and Teacher Education, volume 76 pp. 68-77. https://doi.org/10.1016/j.tate.2018.08.009.

Webster, A. N. (2017). Rural-to-rural translocal practices: Thai women entrepreneurs in the Swedish countryside. Journal of Rural Studies, volume 56 pp. 219-228. https://doi.org/10.1016/j.jrurstud.2017.09.016.

Yampolsky, A. M. \& Amiot, C.A. (2016). Discrimination and multicultural identity configurations: The mediating role of stress. International Journal of Intercultural Relations, volume 55 pp. 86-96. http://dx.doi. org/10.1016/j.ijintrel.2016.09.002.

Zulkarnaen, I. (2013, September 9). Dakwah Multikultural. Paper presented in a visiting professor lecture, STAIN Palangka Raya. 